\title{
Medical, Human Rights and Legal Analysis of the Existence of Lesbian, Gay, Bisexual, and Transgender in Indonesia
}

\author{
Aditya Yuli Sulistyawan ${ }^{1}$, Tri Rahayu Utami ${ }^{1}$ \\ ${ }^{1}$ Lecturer at Faculty of Law, Diponegoro University, Semarang, Indonesia
}

\begin{abstract}
Globalization, which has now crossed the line, has had many impacts on all countries in the world including Indonesia. One of the impacts of globalization is the impact of deviant associations such as LGBT and it affects various countries. The emergence of the LGBT phenomenon, which is currently a hot topic of discussion by various parties in Indonesia, has raised pros and cons views on the legality of LGBT in society. LGBT legalization in various countries is currently encouraging LGBT survivors in Indonesia to urge the government to legalize LGBT. Therefore, this article will discuss the reality of LGBT and its legal arrangements in Indonesia and how to analyze the philosophy of law on the reality of LGBT in Indonesia. The results of the study show that according to the constructivism paradigm in the contextual review of legal philosophy in Indonesia, LGBT is not in accordance with the values of Pancasila as the nation's life guide.
\end{abstract}

Keywords: LGBT,philosophy of law, Indonesia.

\section{Introduction}

Globalization has a great impact on situations and conditions related to social relations, and cooperation between nations takes place quickly so that there is a mutual transfer of lifestyles, cultural values, thinking method, adopted systems, science and others, through relative contact fast too. It is in such an atmosphere and contacts that global political issues, global economy, global culture, and global defense and security develop. ${ }^{1}$ Among the many impacts brought about by globalization, it cannot be denied that there is an impact on social deviations in terms of sexual behavior. The deviant behavior currently being discussed is the emergence of Lesbian, Gay, Bisexual and Transgender (LGBT) groups in society and is still being debated from all sides by various parties.

The history of the emergence of LGBT groups in Indonesian civilization, both documented in scientific and popular works, can be said to have begun to develop since the 1960 s and boom in the 2000 s. $^{2}$ In fact, organizations or advocacy organizations for this group grew in the 1980s, such as: Hiwad (Himpunan Wadam Djakarta); Lambda, Perselin (Indonesian Lesbian Association), all of which serve as a means of communication between perpetrators, observers and supporters of this group. The number of LGBT perpetrators in Indonesia reaches 3 percent of the total population of Indonesia or around 7.5 million people. ${ }^{3}$

The behavior of LGBT survivors, which is currently still hotly discussed, has received special attention from academics abroad as well as the study of feminism. But unfortunately, LGBT people still get an inappropriate position in Indonesian society. This rejection can be seen, among others, by the Islamic Defenders Front (FPI), which was recorded and explicitly restricted the movement of LGBT groups in the public sphere, as well as carrying out physical attacks against this group in various regions in Indonesia. The issue of LGBT is also a concern of domestic academics. This topic is discussed in almost all fields of study of science: law, religion, psychology, education, and sociology, even media and communication. Domestic scientific studies tend to analyze LGBT in particular in relation to its legitimacy in the eyes of law, social, culture, and religion. Humans as one of the contents of the universe are made the object of philosophy which examines it from various aspects. One of them is regarding his behavior. Some of these behaviors are then thoroughly investigated by the philosophy of law. Therefore, this article will discuss in depth the study of Legal Philosophy of the reality of 
Lesbian, Gay, Bisexual and Transgender (LGBT) in Indonesia in order to understand the reality of LGBT from the point of view of legal philosophy. The purpose of writing this paper is to determine the reality of LGBT in Indonesia today so that we can understand the patterns and impacts of LGBT in society which is currently very troubling. In addition, it is also to understand the legal arrangements in Indonesia regarding the reality of LGBT so that it can be seen how the state's attitude towards the existence and reality of LGBT which is currently increasing in number. To achieve this goal, the problems that the authors discuss are the reality of LGBT and the legal arrangement in Indonesia and the analysis of legal philosophy on the reality of LGBT in Indonesia.

The Reality of LGBT and Its Legal Regulations in Indonesia: The definition of LGBT, in general, is associated with the term homosexual, which is the tendency to make someone of the same sex as a sexual partner and/or other emotional relationship. The rise of the LGBT phenomenon in Indonesia is closely related to the trend of liberal countries that provide recognition and a place for the LGBT community in society. LGBT is considered a part of modern society's life style which considers views of heterosexuality as conservative and does not apply to everyone. Social legitimacy arises with a priori scientific and theological defenses to strengthen claims about their existence and social purpose. This situation then made the LGBT movement spread so rapidly as a social epidemic.

In terms of quantity, there is no definite data on the number of LGBT people in Indonesia, but it is certain that it is increasing every year. According to a report from the Ministry of Health quoted from the National AIDS Commission, the number of men who have sex with men, aka gay, has reached millions. Based on the Ministry of Health's estimate in 2012, there were $1,095,970$ MSM both visible and not. More than five percent $(66,180$ people) have HIV. Meanwhile, the UN predicts that the number of LGBT people will be much higher, namely three million people in 2011. In fact, in 2009 the gay population was only around 800,000 people. They take refuge behind hundreds of community organizations that support the tendency to have samesex orientation.

In the perspective of Human Rights, pro-LGBT groups acknowledge that they have the right to vote for LGBT people. Because it is a human right, they demand protection. Human rights are a fundamental right inherent in human beings, universal and eternal, and therefore, must be protected, respected, protected, and not to be ignored, diminished, or deprived of anyone. In the Preamble of the Universal Declaration of Human Rights it is stated that "human rights must be protected by law, so that people will not have to choose the path of rebellion as a last resort to oppose tyranny and colonization".

The implementation of human rights without considering sexual orientation and gender and individual gender identity is not an easy matter. However, nongovernmental organizations (NGOs), human rights and LGBT activists have consistently fought for LGBT recognition and rights, both at the national and international levels. Their endeavors have resulted in new developments on LGBT issues in Indonesia. The political reforms and democratization that have taken place in Indonesia have brought LGBT issues into the spotlight, leading to developments in LGBT organizations. Liberalism that upholds individual freedom has triggered the emergence of LGBT people who, although we think it is not normal, they think are normal and free to do as long as they do not harm others. Individual rights deserve protection, but individual rights are also limited by other individual rights.

Liberalism is one of the philosophical products of the Enlightenment in Europe which is very influential in the development of industrial society today. Liberalism believes that political legitimacy is influenced by the state's respect for the human rights of its citizens. We can see the close connection between liberalism and LGBT with the events of 26 June 2015, which became a historic day for LGBT people. On that day, the US Supreme Court's decision is believed to influence the decisions of many countries to participate in making similar decisions. In addition, there are already 22 countries from 204 countries that have been de facto recognized by the United Nations which fully legalize same-sex marriage in all regions of their country. ${ }^{1}$ Most of these countries are countries with liberal ideologies.

In the legal system in Indonesia, as contained in the 1945 Constitution states "the right to life, the right not to be tortured, the right to freedom of thought and conscience, the right to religion, the right not to be enslaved, the right to be recognized as a person before the law, and the right not to be prosecuted based on retroactive law is a human right that cannot be reduced under any circumstances". This is in accordance with the provisions of Article 2,7 and 22 of the UDHR. 
The state has the obligation to protect the people of Indonesian citizens regardless of their type, ethnicity, religion, race, ethnicity, or minorities and vulnerable groups (meaning that they are vulnerable to violence). The state has an obligation to fulfill the human rights needs of all Indonesian citizens regardless of ethnicity, religion, including minorities and vulnerable groups including LGBT people. In terms of protection, what must be guaranteed and provided in the context of LGBT from a human rights perspective is the protection of their human rights in the form of health insurance to be able to recover from their illness, as stipulated in Article 25 of the Universal Declaration of Human Rights, namely "everyone has the right to an adequate standard of life for health. and the welfare of himself and his family, including the right to food, clothing, housing and health care as well as necessary social services, and the right to security when he is unemployed, suffering from illness, disability, being a widow/widower, reaching old age or other conditions that cause him to be deprived. a living, which is beyond his control".

Based on applicable law in Indonesia, it is possible for people who have undergone sex change surgery to file a gender change in court. This is based on the jurisprudence of court decisions in cases of legal gender change for a male transsexual into a woman, namely Vivian Rubianti (born Iwan Rubianto) in 1973. ${ }^{11}$ There are several rules that indirectly regulate LGBT. Article 292 of the Criminal Code explains that LGBT acts can be punished if the partner is an immature person under the criminal law. Even though the act was carried out without coercion or threat of violence, it is still an act that violates the contents of Article 292 of this Criminal Code. So far, what is prohibited by the Criminal Code is only homosexuals committed against minors. Article 292 of the Criminal Code does not explicitly prohibit homosexuals that are committed between adults. Therefore, it is necessary to emphasize the prohibition of homosexuality and adultery. ${ }^{12}$ On the other hand, the Pornography Law (Law Number 44 of 2008) includes the term "deviant intercourse" as an element of pornography. In the explanation the meaning of this term includes, among other things, "intercourse or other sexual activity with corpses, animals, oral sex, anal sex, lesbian, and homosexuals". Although prohibitions apply to the production and distribution of pornography, these laws are understood by many gay men and lesbian women to criminalize homosexual sex. This is something interesting to discuss because in the regulation there is no prohibition for transgender people regarding deviant sexual relations.

In addition, Government Regulation Number 54 of 2007 concerning Adoption explicitly stipulates that adopting parents cannot be a homosexual couple. Adoption by an unmarried person is not permitted. These various regulations were further reinforced by other regulations, namely the Marriage Law (Law Number 1 of 1974) which explicitly defines marriage as the union between a man and a woman. Therefore, if the marriage occurs, the marriage is only considered never to have existed and no criminal sanctions are given to the perpetrator of the LGBT marriage.

\section{Conclusion}

The exposure of the LGBT phenomenon in Indonesia has become a hot polemic that is discussed from various sides by many parties. The reality of LGBT which is the basis of LGBT legality in Indonesia by pro LGBT people who base the Universal Declaration of Human Rights as its legalization must be reviewed based on the applicable law in Indonesia. Based on Pancasila in the name of Almighty Godhead, then LGBT in Indonesia cannot be legalized because every creature has its own nature, so that the protection of human rights referred to in the Universal Declaration of Human Rights must be adjusted again based on the 1945 Constitution which guarantees the protection of the Indonesian nation, however, protection for the healing of LGBT survivors is not about legalizing them to be accepted as a legally correct group. There are still many pros and cons related to LGBT in Indonesia which is also a moment for every party who is pro or contra to straighten up and present their arguments for the existence of LGBT. This can be initiated by bringing together various parties in a discussion/dialogue to present the arguments of each party in order to find a solution and solution to the LGBT problems that exist in Indonesia today. So it is hoped that with these discussion rooms, LGBT problems in Indonesia can be easily resolved and provide legal certainty whether it is legalized or just a mere hegemony.

Ethical Clearance: This research was ethically approved by Faculty of Law, Universitas Diponegoro, Semarang, Indonesia.

Funding: This research receives external funding from Faculty of Law, Universitas Diponegoro, Semarang, Indonesia. 
Conflict of Interests: There are no conflict of interests.

\section{References}

1. Lubis MS. Serba-serbi politik \& hukum. Sofmedia; 2011..

2. Agung R. Menelisik Perjalanan LGBT di Indonesia. Jakarta: Republika.co.id; 2016.

3. Hasnah H, Alang S. Lesbian, gay, biseksual dan transgender (lgbt) versus kesehata: studi etnografi. Jurnal Kesehatan. 2019 Jun 27;12(1):63-72.

4. Perdana PP. Cari Kaum LGBT, FPI Sweeping Rumah Kos di Bandung. Jakarta: Tempo.co; 2016.

5. Muttaqin I. Membaca strategi eksistensi LGBT di Indonesia. Raheema: Jurnal Studi Gender Dan Anak. 2016;3.

6. Sidabutar H. Mewaspadai 'Virus' LGBT. Republika; 2016.
7. Hartanto HD. Studi Kasus Advokasi Legalisasi Lesbian, Gay, Biseksual, dan Transgender (LGBT) Di Indonesia. Jurnal Indonesian Perspective. 2016 Jul;1(2).

8. Muthmainnah Y. LGBT Human Rights in Indonesian Policies1. Queering Indonesia: Self, Subjectivity \& Crisis. 2016;13.

9. Burchill S. Liberalism. Theories of international relations. New York: Palgrave Macmillan; 2005.

10. House F. Freedom in the world 2014: The annual survey of political rights and civil liberties. Rowman \& Littlefield; 2014 Dec 11.

11. Boellstorff TD. The perfect path: Gay men, marriage, Indonesia. GLQ: A Journal of Gay and Lesbian Studies. 1999;5(4).

12. Pramesti TJA. Prosedur Hukum Jika Ingin Berganti Jenis Kelamin. Hukum Online. Com; 2015. 